DARIUSZ PIĘTKA

\title{
THE ISSUE OF INTELLECTUAL INTUITION IN METAPHYSICS*
}

\begin{abstract}
The article presents problems of intellectual intuition in metaphysics from a semiotic point of view. There are various types of intuition in philosophy: rational intuition, irrational intuition, and sensual intuition. All of them are immediate ways of cognition. Classical metaphysics uses intellectual intuition as its main method to find out and justify its statements. The main problem of intellectual intuition is an intersubjective approach to the object of metaphysics. The main aim of this paper is the objectivization and rationalization of intellectual intuition in language. The semantic notion of meaning and the pragmatic notion of understanding are the fundamental tools which are used to translate the issue of intuition from the subject-matter level into the language level. This operation allows to look at intuition in a non-psychological manner. It enables the objectivization of the method of intellectual intuition in the light of the understanding of meanings.
\end{abstract}

Keywords: intuition; meaning; understanding; separation

1. Introduction. 2. Intuition as intellectual experience. 3. Intuition as an act of understanding the object of cognition. 4. Intuition and induction. 5. Act of intuition in classical existential metaphysics. 6. Intellectual intuition as intuition of meaning. 7. Conclusions.

\section{INTRODUCTION}

Intellectual intuition is one of the types of intuition. Other types of intuition are sensual intuition and irrational intuition (e.g. mystical intuition $)^{1}$. The issue of intellectual intuition is one of the most important philosophical issues of the metaphysics of Thomistic existentialism. It has its roots as early as in Plato and Aristotle. It is particularly in Aristotle that intuition is a way to learn the

* This article was originally published in Polish as: D. Piętka, Kwestia intuicji intelektualnej w metafizyce, Studia Philosophiae Christianae 47(2011)1, 185-204. The translation of the article into English was financed by the Ministry of Science and Higher Education of the Republic of Poland as part of the activities promoting science - Decision No. 676/P-DUN/2019 of 2 April 2019. Translation made by GROY Translations.

$1 \mathrm{M}$. Bunge, Intuition and Science, Englewood Cliffs, New York 1962, ix. 
principles which are non-demonstrable. The Stagirite points out an issue which, in my opinion, casts a shadow on the recognition of the importance of intuition for science and philosophy to the present day. According to him, intellectual intuition as a method is situated outside the system of knowledge, and this is because it is only through intuition that we are able to learn principles; scientific knowledge can be demonstrated, and principles are indemonstrable. Hence the conclusion that intuition which is indemonstrable cannot be a method of scientific knowledge. At the same time, Aristotle admits that the principles of evidence are better known that the conclusions drawn from them, and no type of thought is more precise and certain than intellectual intuition ${ }^{2}$ which is the first cognitive operation.

In the later history of philosophy, intuition was understood in a variety of ways. Descartes understood it differently - as a purely rational operation due to which truths appeared to him in a direct and comprehensive manner. The relationships between, for example, such propositions of mathematics as " $2+2=4$ ", “ $3+1=4$ " and their consequence " $2+2=3+1$ " must have been understood intuitively. The relationship between two first propositions and the third one is given intuitively, directly and without analysis. Spinoza's concept of intuition as having mathematical nature was the first concept to continue this rationalistic approach.

If thee integers are given and 1 is in the same relationship to 2 as 3 to a certain number $\mathrm{x}$, finding $\mathrm{x}$, whose value should be in the same relationship to the third number as the second number to the first one, is done so quickly that it manifests itself as a flash of intuition. There is no need to find the value of $x$ by converting the expression $1: 2:: 3: x$ to the expression $x=(3 \times 2): 1$, from which we obtain the value of $x$. Therefore, according to Spinoza, intuition would be instantaneous inference. Intuition for Aristotle, Descartes and Spinoza was a way of learning about primary theorems - the first true propositions. These types of intuition are classified in the literature

2 Aristotle, Posterior Analytics, 100b. 
as rational intuition, as opposed to irrational types, such as Kant's pure intuition which is the source of synthetic a-priori statements, or Bergson's intuition of experiencing ${ }^{3}$.

Intersubjectivity is a weak assumption of the rationality of cognition. Intuition in the works of Aristotle, Descartes or Spinoza can be called rational intuition, as opposed to Kant's or Bergson's intuition because the results of the first type can be verified with the use of other methods, and the second type does not meet the condition of intersubjectivity as to the possibility of controlling its results. This control can be carried out with the use of a variety of methods, depending on the object of cognition. Aristotle, for example, attempts to provide an elenctic argument for the principle of non-contradiction. His intention is to demonstrate the absurd consequences of rejecting this principle 4 . According to Descartes, the provided examples of relations between propositions can be verified by deduction, just like it was proposed by Spinoza. Let us, therefore, assume, at least as a research hypothesis, that a feature of rational intuition will be the verifiability of its results with the use of some method.

\section{INTUITION AS INTELLECTUAL EXPERIENCE}

Intuition, on the one hand, in Thomist metaphysics plays the role of the essential method of reaching of fundamental propositions, on the other hand, it is used in metaphysics as a method of verification, and thus it makes it possible to confirm the obtained results - which is a justificatory function. The way in which propositions are verified is understood differently than in the distinguished types of Aristotelian or Cartesian intuition. Intuition is treated as a kind of experience - intellectual experience. It exceeds purely sensory experience but, just as sensory experience in exact sciences is the essential method of reaching statements and their verification, intuition is a method allowing

3 M. Bunge, Intuition and Science, op. cit., 5-7, 12.

4 Many scholars accuse him of committing the fallacy of petitio principii in his attempts to justify the principle of non-contradiction. 
to reach metaphysical statements, and then verify them by immediate, intuitive contact with their object. Recognizing intuition as a rational or irrational way of cognition is a decisive factor for the existence of metaphysics, just as recognizing empirical experience as a valuable way of cognition is a decisive factor for the existence of empirical exact sciences.

It is believed that metaphysics has no possibilities to verify its statements based on sensory experience or $a$-priori $\operatorname{cognition}{ }^{5}$, i.e. in a way different than intuitive. The question which should be asked in this context is: in what does the intuitive way of cognition consist and can this method be considered as a rational method? The first part of the question pertains to repetitive operations which in the case of the same object of cognition and with the use of certain rules of procedure will lead researchers to the same cognitive results. The question about rationality, on the other hand, is in the first place a question about the intersubjective verifiability of its results.

Statements that constitute primary premises in metaphysics are the result of intellectual intuition. The same is true for the construction of sciences. Propositions directly based on experience which constitute the primary theorems of empirical theories are obtained using sensory intuition. According to Morawiec, in metaphysics, as opposed to sciences, one can have doubts as to which propositions can be considered as primary premises. At the starting point of the practice of metaphysics, existential and predicative statements are formulated. These statements can be called completely original material of metaphysics which is based on sensory experience (the experience of the content of being) and intuitive cognition (the cognition of existence). According to Morawiec, due to their individual character,

5 This does not mean that there are not trends in neo-Thomism that reject a-priori or empirical verification. Analytical Thomism, in Poland initiated by the "Cracow Circle", would be the first trend; the second was the philosophy of nature, for example in the approach adopted by Kłósak who constructed a method for testing philosophical facts with the use of empiriological facts (i.e. empirical facts interpreted from the philosophical perspective). 
they are not statements belonging to the domain of metaphysics, and therefore they cannot perform the role of the first true propositions of metaphysics in a strict sense ${ }^{6}$. Metaphysical statements are general. Morawiec does not use the term "primary premise", but he refers to the primacy of propositions in metaphysics, or to first propositions within a metaphysical system. It seems, however, that nothing should prevent us from recognizing existential and predicative propositions as the primary premises of metaphysical theory. The same is true for the empirical sciences. General universal propositions, which are the purpose of science, are reached based on specific statements. Such statements are not considered as scientific theorems ${ }^{7}$, but as the primary theorems of scientific theories. Of course, individual objects (e.g. the Sun, the Milky Way, etc.) can also be the subject of scientific inquiry but then they are investigated from the perspective of universal laws of nature. The purpose of sciences, in a very broad sense, consists in seeking to capture the most general regularities in nature and describing them with the use of natural laws. However, to attain this purpose, the sciences must ultimately be based on experience. Since it is always individual objects that are the object of sensory experience, the propositions which are primary premises for inductive inference are not general, but individual propositions. Assuming a static understanding of metaphysics, one can speak of it in the first place as a set of general statements resulting from its characteristic cognitive procedures. Such an approach is associated with the purpose of metaphysics, which means that only theorems which realize the purposes set in its domain are accepted in it. Secondly, it is possible to extend the set of statements which belong to the metaphysical theory by adding all statements which are not general but constitute the foundation for their formulation - as it would be impossible to construct metaphysics without them.

6 E. Morawiec, Podstawowe zagadnienia metafizyki klasycznej, Warszawa 1998, 147148.

7 K. Ajdukiewicz, Subiektywność i niepowtarzalność metody bezpośredniego doświadczenia, in: Idem, Język i poznanie, vol. 2, Warszawa 1985, 372. 
If we assume that existential and predicative propositions are the primary premises of existential metaphysics - which is a position that I advocate - metaphysics will be a type of knowledge immediately based on experience, in which experience will be of an intuitive empirical (the experience of the content of being), and intuitive non-empirical nature (the experience of the existence of being). Such a claim is the result of the belief that existence is something different from the content of being and is not experienced by the senses ${ }^{8}$. However, since the selected aspect in which the objects of immediate experience are investigated is the existential aspect, the notion of being as being is expressed in the process of separation. Its definition is finally obtained through intellectual intuition. An act of intuition is preceded by intellectual operations which formally follow deductive and inductive rules'. Intellectual intuition will be different from the intuition of existence in that it will be an act of understanding, while the intuition of existence will be an act of immediate experience.

In metaphysics, we would be dealing with three types of immediate statements. The first type of statements in the theory of being would be statements expressing given experiences, the second type - the definition of being (formulated through intellectual intuition) as a necessary condition of formulating metaphysical principles; and metaphysical principles would be the third type. According to Morawiec, if existential statements are nonetheless rejected at the point of departure as statements not belonging to theory, then - leaving aside the concept of being as being - the principles of identity, non-contradiction, excluded middle, sufficient reason and

8 Another position in this respect is presented by Gogacz who claims that the content of being is available for immediate cognition, and the affirmation of existence is a consequence of reasoning. "Thus, first in the order of an intellectual encounter with being is the experience of its essence ... the act of existence is specifically concluded by reasoning as the first act of an individual being, the first principle constituting, along with essence, the inner fabric of being" (M. Gogacz, Elementarz metafizyki, Warszawa 1987, 16, 21).

9 D. Piętka, Status metodologiczny tez tomistycznej teorii bytu, in: Nauka i metafizyka, ed. A. Motycka, Warszawa 2010, 61-67. 
finality will be the primary theorems of metaphysics ${ }^{10}$. However, regardless of which statements play the role of primary theorems in metaphysics, general metaphysical statements are a result of intellectual intuition.

\section{INTUITION AS AN ACT OF UNDERSTANDING THE OBJECT OF COGNITION}

In metaphysics it is assumed that intellectual intuition is an act of understanding the object of cognition to develop general concepts and principles of metaphysics. It is preceded by a set of intellectual operations, such as the comparison and combination of data, analysis and inference ${ }^{11}$. It is said that all these operations are so simple that they are immediately obvious. It also applies to deductive and inductive inference that is part of the process leading to an act of intuition. When talking about intellectual operations, I will not mean mental activities, as is often the case, but operations on propositions. This is because what is compared and combined are the contents of concepts (the meanings of names) and statements. Statements are the result of these comparisons. With the use of very simple inference, one can proceed from one statements to another. Operations leading to an act of intuition, although they are very simple and immediately obvious, and in the psychological sense they seem to constitute immediate cognition are, in fact, a kind of reasoning and, objectively speaking, must be classified as a type of indirect cognition ${ }^{12}$. What is immediate is the act of intuition. In the literature, it is said that intuition can be understood both in a broader and a narrower sense. In the broader, operative sense, intuition is a set of activities preparing the act of understanding being as being in its structural, genetic and functional sense. In the narrower sense, intuition is the very act of

10 E. Morawiec, Podstawowe zagadnienia metafizyki klasycznej, op. cit., 148; T. Rutowski, Czy tzw. pierwsze zasady tomistycznej filozofii bytu są naprawdę pierwszymi, Studia Philosophiae Christianae 3(1967)2, 223-227.

11 E. Morawiec, Podstawowe zagadnienia metafizyki klasycznej, op. cit., 94.

12 I pointed it out in an analysis of the method of separation in the article Status metodologiczny tez tomistycznej teorii bytu, op. cit. 
approaching being as being, the result of which is a statements answering questions asked in metaphysics ${ }^{13}$. In this article, I will use a clear distinction between these two aspects, and by intellectual intuition, I will mean the act of understanding being. The primary intention is to clearly discriminate between interpretation procedures and the very act of intuitive cognition ${ }^{14}$. Obviously, interpretation procedures have a fundamental role and essentially affect the result of intellectual intuition.

What is characteristic of intuitive cognition is the fact that it is immediate and obvious ${ }^{15}$. However, unlike the empirical obviousness given in sensory experience, the act of intellectual intuition is accompanied by peremptory obviousness characteristic of necessary theorems ${ }^{16}$. What does this assertion mean? Here we compare the obviousness of the act of cognition and the obviousness of the results of cognitive acts in the form of peremptory statements. Authoritative statements are statements which describe necessary states of affairs and do not allow for any doubt. Non-necessary statements and statements concerning some types of sensory experience can also be peremptory, for example, "I have a toothache". Their feature is doubtlessness. The peremptoriness of an act of cognition would consist, above all, in an experience that excludes doubt. Peremptory obviousness can also be attributed to experience and statements resulting from this experience, although their object may not be necessary, or its occurrence obvious. And here is the fundamental difficulty of the value of intellectual intuition. The subject of cognition may have an experience that will have a feature of obviousness, which will also result in an obvious statements, but this statements may be false. The act of intuition itself does not necessarily lead to the truth. If we apply the framework proposed by Morris to the discussed issue, namely that the process of semiosis consists of three types of relationships - pragmatic, semantic and syntactic relation-

13 E. Morawiec, Podstawowe zagadnienia metafizyki klasycznej, op. cit.

14 J. J. Jadacki, Metafizyka i semiotyka, Warszawa 1996, 148.

15 B. Russell, The Problems of Philosophy, London 1912, 174-185.

16 T. Czeżowski, Filozofia na rozdrożu, Warszawa 1965, 73. 
ships, then the obviousness of a statements will be in the domain of pragmatic relationships, and the truth of a statement within the domain of semantic relationships.

According to the theorists of metaphysics, the theorems of this discipline of philosophy are of an exigence nature because they are based on pointing to the only reason for something. Intellectual intuition is a method that justifies this type of cognition, as its obviousness "not only gives a sense of certainty but also excludes fallacy" ${ }^{17}$. A true and obvious statement is when we have to intellectually recognize a necessary state of affairs given to cognition due to this cognitive content, analytical nature of the proposition expressing it, and obviousness. This operation is not one-off, but it has to be repeated, which allows the control of cognitive results ${ }^{18}$. However, the problem is that depending on the subject of cognition, different conclusions can be reached while adopting the same initial assumptions. It is therefore not necessary to point to one and only cause. An example is the dispute over the existence of substance. In the world, changes can be observed. The data of common cognition and data of scientific cognition lead to the conclusion that there are two different types of changes. On the one hand, these are insignificant changes, such as changes in the position of an atom, change in the colour of one's skin, etc., and on the other hand, significant ones, such as, for example, atomic disintegration or death of a man etc. Thus, two types of changes occur - changes preserving the continuity of an object, and changes which cause an object to cease to exist or come into being. The ascertainment of two types of changes leads to the conclusion that in an object changing inessentially there is the subject of properties called substance, and if object changes inessentially inessential properties called accidents ${ }^{19}$.

Eukasiewicz, for example, reaches different conclusions based on the same assumptions. Namely, he states that objects have proper-

17 S. Kamiński, Możliwość prawd koniecznych, in: Idem, Jak filozofować, Lublin 1989, 122.

18 Ibid, 123.

19 A. B. Stępień, Wprowadzenie do metafizyki, Kraków 1964, 101. 
ties that change and properties that are unchangeable. And what is non-contradictory is the object. Therefore, Eukasiewicz does not differentiate between changeable features and unchangeable subject, but he differentiates between changeable and unchangeable properties, where a change of the latter causes the annihilation of the whole object. Eukasiewicz states explicitly that to justify the existence of an object which is changeable, but nonetheless has a relation of identity with itself, one does not need to refer to the metaphysical assumptions about unchangeable substance and changeable properties since it is sufficient to assume that changing objects comprise groups of changeable and permanent properties ${ }^{20}$.

\section{INTUITION AND INDUCTION}

Since intellectual intuition is a type of immediate cognition, experienced in a given moment by a particular person, a problem arises concerning its intersubjective nature. In a sense, this is analogical to the non-intersubjective character of empirical experience ${ }^{21}$. However, the difference is that, in most cases, phenomena of a certain type which are the object of sensual cognition, can be learned repeatedly by a number of people. What raises an objection here is the reference to the type of object, which assumes that a particular experience of a researcher will never be repeated as the same experience. Moreover, intellectual intuition does not have a character that can be proven by the senses, which is why the belief in its justifying character is very weak. However, the issue of intersubjectivity can be approached in a slightly different way. The object of intellectual

$20 \mathrm{~J}$. Łukasiewicz, Analiza i konstrukcja pojęcia przyczyny, Przegląd Filozoficzny 9(1906)2-3, 146.

21 Ajdukiewicz wrote bout the subjective character of direct empirical methods He claimed that a proposition obtained based on the method of direct experience can be recognized only once by a small group of researchers. Therefore, it is not a method that allows everyone to verify many times the truth of a proposition obtained with its use. This is therefore not an intersubjective and repetitive method. K. Ajdukiewicz, Subiektywność i niepowtarzalność metody bezpośredniego doświadczenia, in: Język i poznanie, op. cit., 371. 
intuition cannot be a domain of objects belonging to the real world, or the domain of language (meanings of language expressions).

I assume, like Ajdukiewicz does, that each person can understand a certain expression in the first place as to its object of reference, secondly - as to the way of reference, thirdly - a s to emotional undertone, and fourthly - as to attitude ${ }^{22}$. We are interested only in the first two ways of understanding expressions. According to Ajdukiewicz, person $V$ understands expression $A$ when $V$ upon hearing or seeing expression $A$ directs their thought to object $x$ different from that expression ${ }^{23}$. Apart from the fact that a language user refers by means of expression $A$ to object $x$, they always do so in a certain way. One person asked whether a given object is a square, will answer in the affirmative because the geometric shape to which they refer is a rectangle with four equal sides. Another person will give the name of a "square" to a shape because it has two equal diagonals, intersecting each other at a right angle exactly in the middle of their lengths. Each of these people understands the name "square", but each of them differently. The way of reference in this example will be the properties of the square. Even if one user of language understands "square" exclusively in the first way, and in no other way, and the second user understands it in another way, each of them can, based on their mathematical knowledge, deduct from the properties of a square known to them, the properties used to identify the shape as a square by the other user. Then both of them will understand the name "square" in the same way not only due to the object, but also due to the way in which it is referred to.

Individual people, when learning a (common or scientific) language, learn the ways of referring to objects. By analyzing the way in which users of a language come to capturing the meaning of a particular object we can come closer to the way of capturing with the use of thought what real objects are. This will not be about the psychological aspect of the process, but rather about indicating certain formal conditions

22 K. Ajdukiewicz, Logika pragmatyczna, Warszawa 1975, 23.

23 Ibid, 19. 
that are necessary to understand a previously unintelligible expression. It will be limited to the concept of understanding as the knowledge of meaning proposed by Ajdukiewicz (understanding of an expression as to the way in which an object is referred to) or the knowledge of reference (understanding of the expression as to its object).

For example, to understand the name "table", what seems important is the genesis of capturing the properties which allow identifying some objects as tables. Let us assume that person $V$ is in a room in which there is a table. In the same room, there is also person $W$, who, pointing to the object with a table-top standing on four legs, asks person $V-$ "is it a table?". If person $V$ answers that the object indicated by $W$ is not a table, then we may suppose that $V$ does not understand the meaning of the word "table" in English. If we ask person $V$ to indicate a table among the objects in the room and that person would be unable to do so, this would be definite evidence that $V$ does not understand the meaning of the word "table" as to the object. In other words, $V$ cannot indicate an object to which the name "table" refers. Since the asked person is unable to answer the question asked by $W$, therefore he or she does not understand the word "table" as to the object. If, however, $V$ does not speak any other language than English, then the answer provided by $V$ will mean, in the first place, that $V$ does not understand the word "table" assigned to it in the English language and, secondly, that he or she does not know what is the object referred to by the name "table".

Understanding what is an object belonging to the physically existing world is usually reached by way of induction. The same is true when we learn meanings assigned to expressions in a language. This inductive way ultimately leads to an act of intuition consisting of a one-time and holistic understanding of what an object is or understanding the meaning of some name. Let us assume that a small child learning a language, pointing to an object with four legs and a table-top on which there are different objects, asks "what is it?". A person to whom this question is addressed, answers "this is a table". Thus, the name "table" is assigned to a specific object. The same child, in a other room, pointing to a table-top placed on one 
central leg, asks "what is it?". The answer provided is "this is a table". The same name is assigned to another object than previously. The same answer will be provided when the child asks about an object consisting of a round table top with three legs, a rectangular table top with a dozen legs, and so on. Each time, the name "table" is assigned to another object, which nonetheless has a shared function and properties. At some point, the child will understand what it means to be a table, and thus understand the meaning of the name "table". On the one hand, one includes in a single act what an object is and the meaning of the name used to refer to it. If someone pointing to a table top with some objects lying on it, suspended rigidly on mounting arms fastened to the ceiling asks the child - "is this a table?", and the child answers "yes, it is", although he or she has never seen such an example of a table before, this would mean that he or she understands the meaning of the term "table" assigned to it in the English language. This is because he or she assigns the name "table" to an object that meets the conditions of being a table.

\section{ACT OF INTUITION IN CLASSICAL EXISTENTIAL METAPHYSICS}

Let us assume, as Ajdukiewicz did, that any name $n$ means object $x$ if and only if the name $n$ can be truthfully predicated about each $x^{24}$. On these grounds, we can define the notion of understanding as to the object. If person $V$ understands the meaning of the name "table" as to the object, at least in one language, this means that $V$ can truthfully predicate the name "table" about such objects $x$ which are tables; and vice versa, if $V$ can truthfully predicate the name "table" about such objects which are tables, then they can understand the meaning of the name "table" which is used to refer to this object in at least one language. Therefore, extending our deliberations to any names, we can say that person $V$ understands the meaning of the name $n$ as to the object in at least one language if and only if $V$ can truthfully predicate the name $n$ about such objects $x$ which are $n$.

$24 \mathrm{Ibid}, 40$. 
Using this definition, for example, to the notion of being as being, it can be concluded that a person who understands the name "being as being" in the $J$ language (e.g. the language of metaphysics) as to the object, can predicate the name "being" about each object $x$ which is a being. The presented notion of understanding as to the object is a notion which is the most fundamental to it.

In order to predicate the name "table" about a certain object truthfully and in accordance with understanding, a user of a language has to have a method that allows him or her to decide whether he or she can assign the name "table" to this object. The method consists in assigning the name "table" to every object consisting of a table top at a certain distance from the ground whose function is to enable the convenient use of objects without the need of bending or lifting these objects. Ajdukiewicz gives an example of a mathematical object - hexagon. The method, in this case, would consist in giving the name "hexagon" unconditionally to every geometrical shape based on the information that this shape has 9 diagonals ${ }^{25}$. In these examples, it turns out that a language user can assign certain names to objects unconditionally, while other names cannot be assigned unconditionally. The unconditionality of assignment here is related to the sharpness of the scope of this name. It is known that in maths, notions are well-defined. It is not the case of real-world objects. Here, the meanings of expressions can be vague, they can change depending on changes in objects themselves, in particular in their functions - this applies primarily to intentional objects. Objects belonging to the world of nature and their (usually) qualitative qualifications are also re-definable. Such a notion as good, beautiful or fair have partially changed their meaning in the course of history. In this context, we can say that the meaning of the name hexagon would be unchangeable in language $J$ in the course of history. This is because today the explanation of what properties are characteristic of a geometric shape called "hexagon" would probably be the same as it was in the times of Euclid. The notion of hexagon 
did not change significantly during this time. Perhaps the only exception is that one should mention that hexagon retains the said properties in the Euclidean space.

It seems to be different for the second type of objects. Probably we would provide a different explanation of what beauty is than the one that would have been provided by Plato; our understanding of freedom or equality between people would also differ. But we also have a different understanding of what are such objects as the Earth, Sun, Moon, etc. This is related to having a method allowing us to ascertain what are the abovementioned objects and what features they have. In the antiquity, the Earth was a disc surrounded with the waters of the river Oceanos which at night transported the Sun from the west to the east so that it could start its journey through the sky in the morning.

An analogical situation is with the notion of being as being. The act of understanding what a particular being is, and the act of understanding the meaning of the name "being" significantly depend on our method of the cognition of the world. In the Aristotelian or Thomist current of the classical metaphysics, there are several methods of arriving at the notion of being as being. The most important of them are abstraction and separation. These methods are operations preparing the act of intellectual intuition whose object is being as such. As a result of these operations, different concepts of being are obtained, but the principles and most theorems concerning the structure of being remain the same, or at least distantly similar. Individual steps of separation, in simple terms, can be presented as follows ${ }^{26}$. Existential statements are made as a result of collecting experience data:

$$
\text { (i) } \operatorname{ex}\left(A_{1}\right), \operatorname{ex}\left(A_{2}\right), \operatorname{ex}\left(A_{3}\right), \ldots, \operatorname{ex}\left(A_{n}\right) \text {. }
$$

The abbreviation "ex" is a predicate of "exists", while $A$ is any individual name.

26 What I am interested in are only the relations between propositions and I do not consider mental activities of the subject of cognition. 
As a result of the analysis, one comes to the conclusion that individual beings have certain content, i.e. Jan Kowalski is a shoemaker, Anna Nowak is an accountant, Burek is a dog, and so on. By marking different properties with the constants $a_{1}, a_{2}, a_{3}, \ldots, a_{n}$ can be written down as follows:

$$
\text { (ii) } A_{1} \varepsilon a_{1}, A_{2} \varepsilon a_{2}, A_{3} \varepsilon a_{3}, \ldots, A_{n} \varepsilon a_{n} .
$$

From (i) and (ii), we receive

(iii) $\operatorname{ex}\left(A_{1}\right), \operatorname{ex}\left(A_{2}\right), \operatorname{ex}\left(A_{3}\right), \ldots, \operatorname{ex}\left(A_{n}\right) \wedge A_{1} \varepsilon a_{1}, A_{2} \varepsilon a_{2}, A_{3} \varepsilon a_{3}, \ldots, A_{n} \varepsilon a_{n}$.

On this basis, it is claimed that if some individual $A_{1}$ is a being as being $B$, then it is something that exists and has some specific content:

$$
\text { (iv) } \begin{gathered}
A_{1} \varepsilon \boldsymbol{B}, A_{2} \varepsilon \boldsymbol{B}, A_{3} \varepsilon \boldsymbol{B}, \ldots, A_{n} \varepsilon \boldsymbol{B} \rightarrow \operatorname{ex}\left(A_{1}\right), \operatorname{ex}\left(A_{2}\right), \operatorname{ex}\left(A_{3}\right), \ldots, \\
\operatorname{ex}\left(A_{n}\right) \wedge A_{1} \varepsilon a_{1}, A_{2} \varepsilon a_{2}, A_{3} \varepsilon a_{3}, \ldots, A_{n} \varepsilon a_{n} .
\end{gathered}
$$

Formula (iv) can be considered a deductive conclusion from (iii) and the right of simplification. However, metaphysics claims that the process of specifying being as being by means of cognition, the purpose of which is to form an atheoretical notion of being as being, that is, a notion of being that is not implicated in any theor $y^{27}$. However, I think that in conducting analyses, a metaphysicist uses some rules that organize their thinking. Even if the metaphysicist did not use them consciously, it is possible to extract these rules and check the accuracy of passing from one sentence to another. Still, from (iv), one receives a general conclusion concerning what a being is:

$$
\text { (v) } \forall A[A \varepsilon \boldsymbol{B} \rightarrow \operatorname{ex}(A) \wedge A \varepsilon a] \text {. }
$$

27 E. Morawiec, Podstawowe zagadnienia metafizyki klasycznej, op. cit., 90. 
The symbol " $a$ " represents any content. It is claimed here that every being is any existing content. This is an inductive generalization of what is given in an experience, the subject of which are individuals, and what is expressed in the sentence (iv). The final stage is intellectual intuition, which would consist in understanding that if something exists and has some content, it is a being. Hence, the definition of being as being is the result of an act of intellectual intuition and could be written down in this way:

$$
\text { (vi) } \forall A[A \varepsilon B \leftrightarrow \operatorname{ex}(A) \wedge A \varepsilon a] \text {. }
$$

Intuition is a one-off understanding and is preceded by deductive and inductive inferences. According to Stępień, as a result of constant contact with individual beings, a metaphysicists understands what a being is, i.e., they see that for something to be a being, it must exist as a specific content ${ }^{28}$. This constant contact could be understood as a constant confirmation of what has been understood.

The above analysis shows that the act of intuition in classical existential metaphysics is prepared by means of reasoning which, due to its rules, does not ensure the reliability of the final conclusion. On the one hand, these operations are very simple; on the other hand, the result of the whole procedure has no counter-example in the world, so the conclusion is obviously apodictic, consisting in the conviction of its unquestionability. However, the only statement that is reached here is that it is one thing to be and another thing to be something. It seems that at this stage of development of metaphysics, one cannot speak of existence as an act of being. The above analysis made it possible to precisely identify the statement resulting from an act of intellectual intuition, without burdening the statement with a subsequent interpretation ${ }^{29}$.

28 A. B. Stępień, Wprowadzenie do metafizyki, op. cit., 54.

29 The separation itself and its result can be understood in various ways. 


\section{INTELLECTUAL INTUITION AS INTUITION OF MEANING}

If person $V$, pointing to a dog, would ask man $W$ in English: "is it a being?", pointing to any existing object, and man $W$ would give a positive answer because he has a method that allows him to decide whether a given object is a real being or not, it means he knows the meaning of the name "being" (we exclude blind guessing here, of course). However, it is not known whether he would understand the name "being" in the same way as person $V$. In classical essential metaphysics, as for example in traditional Thomism, the function of existence in the structure of being is understood differently, and thus the meaning of the word "being" is different than in existential metaphysics. Thus, as was the case with the name "hexagon", two people can understand the name "being" in the same way as to the object and differently as to the reference.

Person $V$ understands the meaning of the name $n$ in language $J$ if and only if, truthfully and based on the understanding of the manner of reference, $V$ can indicate the name $n$ of the object $x$. If one has a method by which he can assign a name to an object, then he knows what that object is. Hence, person $V$ knows what $x$ is if and only if $V$ understands, in at least one language, the meaning of the word $n$. Therefore, the knowledge of what an item is consists in knowing the meaning of the name of the item in the language used by its user. Our analyses also show that both the knowledge of the meaning of a name and the knowledge of what is the object of cognition do not come from nowhere, but remain closely related to the knowledge of certain characteristics or some qualifications that it has. In other words, there would be no meaning of the word "table" if we did not ultimately know what a table is. However, such knowledge always has a sign character. Thus, anyone who understands the word "table" in English knows what a table is. In both cases - in case of the word "table" and in case of a material table - the object of understanding is different. In both acts of intuition - understanding, the object is indicated through the same features. If someone wants to explain the meaning of the name "table" using a definition, he will use names of features co-denoted by this name. If someone wants to explain what a table is using a definition, he 
will point to the features of this object. Both are about indicating the features or certain qualifications through which we relate to the things of this world. In the context of this definition, a well-known epistemological problem arises, whether human thinking is always linguistic or not. The problem of the relationship between thought and language, and in particular the question whether thinking is always linguistic, is left unanswered, as it lies beyond the capabilities of the method applied here. However, our analyses only concern the field in which we can say that thinking of the linguistic nature.

Between these two fields of cognition - real and linguistic, there are relationships that make it possible, when talking about things, to draw conclusions about the meanings of linguistic expressions or, when talking about meanings, to draw conclusions about things. Thanks to the ability to objectify intellectual intuition by transferring it to the language level, it is possible to show its intersubjective character and explain in a simple way, accessible to everyone, what intuitive cognition, which seems extremely mysterious and irrational for many people, consists in. Language not only allows us to check whether we understand certain meaningful terms in the same way, but it also allows us to check the truthfulness of the first metaphysical premises obtained through direct intuitive experience. They can be derived in a deductive way from general statements of metaphysics, treating them as consequences of metaphysical hypotheses.

The objection that can be made to the considerations presented in the article is as follows: in the intuition of meaning, we use features, just as in the understanding of genres, types, etc. Classical metaphysics, on the other hand, uses an analogous language, whose expressions have meanings that are not limited by a certain features or set of features, but express beings in their similarities and differences from other beings. However, I think that the issue of intuition raised by me in this way can be defended even in relation to analogous language, assuming that we will not take the view of elusiveness of the meanings of analogous terms, but rather try to make them as precise as possible, as the philosophers of the Cracow Circle used to do in the past.

Another accusation that can be made is that of moving away from metaphysical realism, because how can one speak of a world external to 
language and independent of language on the basis of the knowledge of meanings? I would like to point out here that I accept that the meanings of expressions referring to non-linguistic objects have their own objective origins and are the result of certain generalizations. When confronted with the sphere of reference, the meanings and thus the understanding of reality itself are often modified. However, it is possible to speak about things on the basis of the knowledge of meanings. For example, let us use the expression "capital of Poland". If I know the meaning of this phrase, I will be able to easily assign to the object denoted by this phrase certain features co-denoted by the name "capital of Poland" based on certain knowledge. Similarly, if I know the meaning of the word "being", I know what being is, etc. Therefore, it is not a matter of believing that meanings determine the statements.

\section{CONCLUSIONS}

The above-mentioned proposal to treat intellectual intuition as intuition of meaning is a certain proposal for discussion, aimed at objectifying it with linguistic tools and, consequently, showing its intersubjective character, which is often denied or even rejected completely ${ }^{30}$. On the other hand, there seems to be a serious rationale to consider intuition primarily as cognitive acts in the context of discovery. Operations preparing an act of intuition are not reliable. Results of intuitive acts can be false. An example could be the understanding of existence - in existential metaphysics it is an act of being, and in essential metaphysics it is the property of being. Of course, in both cases, different procedures are used to prepare the act of intuitive cognition but the goal is determined by the same question - what it means to be a being as such (being as a being). A different starting point is taken and different analyses are performed.

When it comes to intellectual intuition in metaphysics, it is not only about the act of intuition, but also, and perhaps even more importantly, about objectifying the methods allowing to understand

30 J. J. Jadacki, Metafizyka i semiotyka, op. cit., 152. 
transcendental concepts and the first principles of being. In the definition that is results of act of intuition, which results in a definition, that the metaphysicist articulates the concept of being as being. The problem of the intersubjective nature of intuition in metaphysics arises mainly when we try to understand transcendental concepts, the scope of which is a collection of all existing objects.

\section{BIBLIOGRAPHY}

Ajdukiewicz K., Logika pragmatyczna, Warszawa 1975.

Ajdukiewicz K., Subiektywnośi i niepowtarzalność metody bezpośredniego doświadczenia, in: Idem, Język i poznanie, vol. 2, Warszawa 1985.

Aristotle's Prior and Posterior Analytics, A revised text with introduction and commentary by W. D. Ross, Oxford 1949.

Bunge M., Intuition and Science, Englewood Cliffs, New York 1962.

Czeżowski T., Filozofia na rozdrożu, Warszawa 1965.

Gogacz M., Elementarz metafizyki, Warszawa 1987.

Jadacki J. J., Metafizyka i semiotyka, Warszawa 1996.

Kamiński S., Możliwość prawd koniecznych, in: Idem, Jak filozofować, Lublin 1989.

Łukasiewicz J., Analiza i konstrukcja pojęcia przyczyny, Przegląd Filozoficzny 9(1906)2-3, 105-176.

Morawiec E., Podstawowe zagadnienia metafizyki klasycznej, Warszawa 1998.

Piętka D., Status metodologiczny tez tomistycznej teorii bytu, in: Nauka i metafizyka, ed. A. Motycka, Warszawa 2010, 61-67.

Russell B., The Problems of Philosophy, London 1912.

Rutowski T., Czy tzw. pierwsze zasady tomistycznej filozofi bytu sq naprawde pierwszymi, Studia Philosophiae Christianae 3(1967)2, 215-229.

Stępień A. B., Wprowadzenie do metafizyki, Kraków 1964. 